\title{
My Last Word
}

his is my last perspective as President. A year has passed and much has transpired. To start, I want to thank John Pineau-our "new" Executive Director. He has done an amazing job and has given his all to see that the CIF/IFC is the best it can be. Johnyour dedication has truly been inspiring, as is all of your hard work, and I thank you for it. Keep up the good work! I also want to thank Sue and Cherry for all the years of dedicated service and for putting up with John as he transitioned into the ED position; Sue and Cherry you have been steadfast through the years, and I thank you for all of your commitment to the Institute. Thanks also to our FedNOR Intern Julia Hancock - although you have only been around for a few months Julia, your contribution to the Institute has been enormous already, and we are grateful.

Now on to The Forestry ChronicleRon, Brian, Spike and all of the authors and associate editors-thank you for making The Forestry Chronicle the upstanding journal that it is! Granted there are some changes which may have to occur to make it more relevant to our ever-changing membership dynamic, but your consistent dedication and pure brilliance have made The Forestry Chronicle what it is, and have kept it on time and always of high quality throughout the years-thank you! Lastly to my fellow Executive-my journey started with Michael, Richard and Roxanne, and as I move to Past President and we say goodbye to Chris and welcome Anne, I very much realize that the team has always been dedicated, hard working and committed. I know as I move on that the fundamental core values that have always been present in past Executive groups are there to stay in the new Executive of Fred, Peter and Anne. Thank you for all of your enthusiasm and effort over the past year; and I look forward to working with you over the next and last year of my term-Go Fred Go!

The past year has been both exciting and challenging. We lost quite a number of members from Alberta, but we also gained back quite a number of members-both old and new. We embarked on a Rejuvenation Exercise with Change Inc., a pro-cess to revitalize ourselves so as to be stronger as we progress into our second century. We are now exploring many exciting partnership opportunities, some of which have already resulted in new value and opportunities for our members, and diversification of the Institute's revenue; I am confident that there will be much more of this to come.

As an Institute, we still have a long way to go to become truly sustainable. We need more involvement from our members and we need more new members. In short we need to find that "value" we are seeking in order to be of value to a larger group. To date we still have not found the "magic" pill, but we are moving in the right direction. The wind is blowing and rejuvenation is on that wind. With continued perseverance

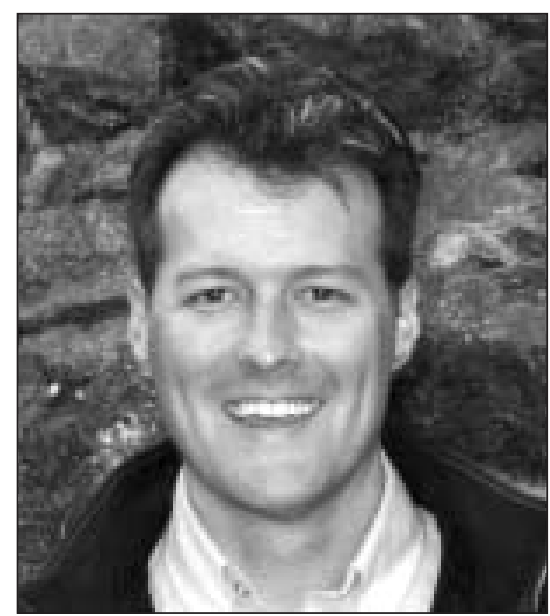

Doug Stables, R.P.F. CIF/IFC President/président

and dedication, we will bolster our sails and move steadily forward. I believe we are on the right track; and although the process of rejuvenation we started a year ago has a long way to go, we are moving forward slowly but surely, one step at a time, and with each step we move closer to our goal, and that is what really matters.

In conclusion, I want to thank the membership. It is your Institute, and it is your hard work and dedication that makes the CIF/IFC what it is today and into the future. Please stay the course, continue to grow, continue to challenge, and I can assure you that the CIF/IFC will prosper for another 100 years. But remember you must stay active and engaged, you must stay involved, and more importantly you must be proactive both in recruiting new members and also in being the Voice of Forest Practitioners in Canada.

\section{Mon dernier mot}

eci est la dernière chronique V Perspective que je rédige en tant que président. Une année complète a passé et bien des choses se sont produites. Pour commencer, j'aimerais remercier John Pineau-notre « nouveau » directeur général. Il a fait un travail incroyable et a tout donné pour améliorer au maximum le CIF/IFC. John-ton dévouement est une vraie source d'inspiration, tout comme ton travail acharné, et je t'en remercie. Continue ton bon travail ! Je remercie également Sue et Cherry pour toutes leurs années de service dévoué et pour avoir supporté John pendant sa transition au poste de DG; Sue et Cherry, vous êtes loyales à l'Institut depuis des années, et je vous remercie pour l'ampleur de votre engagement. Merci aussi à notre stagiaire de FedNor, Julia Hancock. Julia, même si tu es parmi nous seulement depuis quelques mois, ta contribution est déjà énorme et nous en sommes reconnaissants.

Passons maintenant au Forestry Chronicle—à Ron, à Brian, à Spike et à tous les auteurs d'articles et rédacteurs en chef adjoints, merci pour avoir fait du Chronicle un journal estimable ! Il est vrai qu'il faudra peut-être $y$ apporter certaines modifications pour qu'il reflète mieux la composition en 
constante évolution de nos membres, mais votre dévouement assidu et votre génie ont fait du Forestry Chronicle ce qu'il est devenu, une revue de grande qualité toujours publiée ponctuellement depuis des années. Merci ! Je veux aussi m'adresser à mes consœurs et confrères du bureau de direction. Mon aventure a commencé avec Michael, Richard et Roxanne, et alors que je deviens " ancien président », que nous disons adieu à Chris et souhaitons la bienvenue à Anne, je constate à quel point j'ai toujours été entouré d'une équipe sérieuse, travaillante et dévouée. Je partirai en sachant que les valeurs fondamentales qui ont toujours caractérisé les membres du bureau de direction sont partagées par le nouvel exécutif formé de Fred, Peter et Anne. Merci à tous pour votre enthousiasme et vos efforts au cours de la dernière

\section{"Rooting Above the Competition"} Jiffs'. Forestry Pellets
"The only True Complete Air Pruning System

\author{
Roots Store Carbon, \\ Roots Produce Wood Fibre, \\ Roots Prevent Erosion, \\ Roots Filter Water, \\ Roots Are The Life Line to \\ Strength \& Stability. \\ Forest Sustainability is \\ Dependent on Roots. \\ Eliminate Root Deformation ... \\ Jiffy Seedling Plugs Can ... \\ Other Choices Can Not
}

Jiffy ... "Roots That Stand Up"

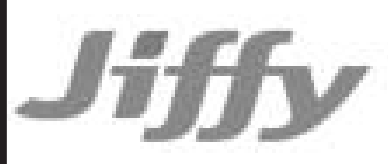

Let's grow together

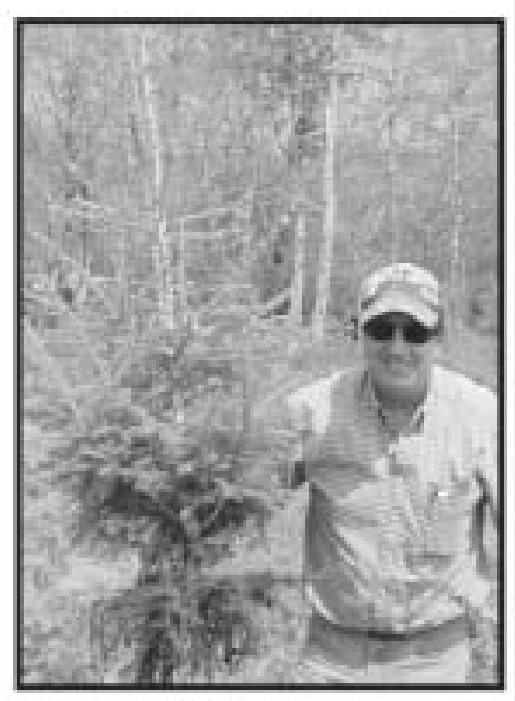

Jiffy Specialized Forestry Tree Growing Kits "Now" available in Generic labels or custom labels

For further information please call: Don Willis, R. P. F. (705) 495-4781

-www.jiffypot.com•Email: jiffy@vianet.ca année; j'ai déjà hâte de travailler avec vous durant la prochaine, et dernière, année de mon mandat-Vas-y, Fred!

L'année qui vient de s'écouler a été à la fois stimulante et pleine de défis. Nous avons perdu plusieurs membres de l'Alberta, mais nous en avons retrouvé d'autres et recruté de nouveaux. Nous nous sommes engagés dans un exercice de rajeunissement avec Change Inc., un processus de revitalisation qui renforcera l'Institut pour l'aider dans son deuxième siècle d'existence. Nous évaluons présentement plusieurs possibilités intéressantes de partenariat. Certaines de ces occasions ont déjà produit une valeur nouvelle, des possibilités pour nos membres ainsi que la diversification des revenus de l'Institut. Je suis convaincu que ce n'est que le début d'une nouvelle tendance.

En tant qu'Institut, il nous reste beaucoup de chemin à parcourir pour être entièrement viable. En plus de nouveaux membres, il nous faut des membres qui s'impliquent plus. En bref, si nous voulons bien servir l'ensemble du groupe, nous avons besoin de gens de valeur. Nous n'avons pas encore trouvé la « pilule magique » qui réglera nos problèmes, mais nous avançons dans la bonne direction. Un vent de renouvellement souffle sur l'Institut. Avec notre persévérance et notre dévouement constants, nous hisserons nos voiles et nous avancerons hardiment vers l'avenir. Je suis convaincu que nous allons dans la bonne direction. Bien que le processus de rajeunissement entamé il y a un an soit loin d'être terminé, nous procédons lentement mais avec assurance, un pas à la fois. Et, ce qui importe le plus, chacun de ces pas nous rapproche de notre objectif.

En conclusion, je tiens à remercier nos membres. Cet institut est le vôtre, et ce sont votre labeur et votre dévouement qui font du CIF/IFC ce qu'il est maintenant et ce qu'il deviendra. Continuez à nous suivre, à vous multiplier et à nous lancer des défis, et je vous garantis que le CIF/IFC prospérera pendant un autre siècle. Mais rappelezvous qu'il vous faut rester actif, engagé et impliqué. Et surtout, vous devez faire preuve d'initiative pour recruter de nouveaux membres et pour faire de vous-même le porte-parole des professionnels de la foresterie au Canada. 